\title{
Experimental Cancer Models
}

\author{
Seher Yılmaz ${ }^{1 *}$, Adem Tokpınar ${ }^{1}$ and Seda Avnioğlu ${ }^{2}$ \\ ${ }^{1}$ Department of Anatomy, Yozgat Bozok University, Turkey \\ ${ }^{2}$ Department of Anatomy, Alanya Alaaddin Keykubat University, Turkey
}

*Corresponding author: Seher Yilmaz, Faculty of Medicine, Department of Anatomy, Yozgat Bozok University, Yozgat, Turkey.

To Cite This Article: Seher Yllmaz, Experimental Cancer Models. Am J Biomed Sci \& Res. 2019 - 6(3). AJBSR.MS.ID.001030. DOI: 10.34297/ AJBSR.2019.06.001030

Received: 眥 November 15, 2019; Published: November 22, 2019

\begin{abstract}
Treatments in the field of cancer are continuously improving. No matter which model is used, using animal models in drug development research has become a necessity. Although cell culture and molecular biology have become prominent in recent years, the responses of metabolism to the drugs used have necessitated the use of an animal model in research. The use of spontaneous or transplanted tumors with chemical carcinogens is common in experimental cancer studies. In recent years, with the introduction of transgenic animal models, scientific and commercial developments are taking place. In this article, we will examine the methods used in experimental cancer models.
\end{abstract}

Keywords: Cancer Models; Cancer; Experimental Animal Models

\section{Introduction}

Cancer is an increasingly important health problem all over the world and causes both material and moral losses for people [1]. Diagnosis of cancer causes psychological problems and medical interventions applied throughout the process may adversely affect the lives of patients [2]. Decrease in quality of life, psychological problems, especially depression and anxiety are mostly experienced [3].

Cancer is a disease that accounts for a significant proportion of deaths worldwide, despite significant advances in medical technology for its diagnosis and treatment [4]. Commonly used treatments for cancer treatment are chemotherapy, radiotherapy and surgery [5].

In general, after the diagnosis of cancer, the effects of the stages during and after treatment are evaluated separately [6]. Studies for the newly diagnosed cancer stage vary. In experimental studies, experimental animals are frequently used for clinical observations $[7,8]$. In animal experiments for cancer treatments, often plant extracts have an important place in research [9-11].

\section{Physical and Chemical Carcinogen Models}

\section{P388 Leukemia}

Lymphatic leukemia is induced by administering 3 -methylcholanthrene $(20 \mathrm{mg} / \mathrm{kg})$ to DBA $/ 2$ mice intraperitoneally.
This method was first used in 1955, and until 1970, more than 400 thousand compounds were tested with the P388 Leukemia model. P388 leukemia tumor formed in DBA / 2 mice can be passaged by intrapertonal administration to CD2F1 mice as $1 \times 106$ cells in 0.1 ml suspension.

\section{L1210 Leukemia}

When DBA / 2 mice are administered intraperitoneally in 3-methylclonathrene $(20 \mathrm{mg} / \mathrm{kg}$ ) ethyl ether, the lymphoid is formed. This method has been used since 1948. The potential for tumor formation is very high. As in the P388 Leukwmi model, CD2F1 mice can be passaged by intraperitoneal administration. 0.1 ml suspension contains 1 x10 5 cells.

\section{DMCA-Induced Breast Tumor}

It is a mammary gland-derived tumor, especially in Spraque Dawley rats, by thesis dose administration using dimethylbanz (a) anthracene (DMBA) of polycyclic hydrocarbons 7,12. Female rats aged 8-10 weeks are administered by gavage by dissolving in 1 $\mathrm{ml}$ of sesame oil, corresponding to $12-20 \mathrm{mg}$ of DMBA per animal. This method, which shows good adhesion with respect to the dose, is a useful method to evaluate the effects of anticancerogenic agents. However, $60 \%$ of the model created by DMBA application is carcinoma and $40 \%$ is benign fibroadenoma. 


\section{Colon cancer}

DMH (1.2 Dimethylhydrazine) is a column-specific carcinogen and a toxic chemical that pollutes the environment. When $20 \mathrm{mg} /$ $\mathrm{kg}$ DMH in $1 \mathrm{ml}$ EDTA is administered by subcutaneous injection to the groin area, a model of cancer similar to colon cancer in humans is formed. 32. Adenocarcinoma structure is seen at histopathological examination at the end of the week.

\section{Gastric cancer}

After intraperitoneal injection of 100 ppm N-methyl-N-nitro$\mathrm{N}$-nitrosoguanidine (MNNG) into 6-week-old rats, MX Furanone is added to the animals by adding $30 \mathrm{ppm}$ of drinking water. Adenocarcinoma type cancer model emerges after 57 weeks of application. Increased cell proliferation in the gastric mucosal epithelium and atypical hyperplasias in the pylori are seen.

\section{Transplantable tumor models}

It can be derived from suspensions obtained from spontaneous tumors. They show kinetic similarity to human cancer types. It also plays an important role in the development of chemotherapeutic drugs in understanding the biology of carcinogenesis. Solid tumors are transplanted intraperitoneally, intramuscularly, subcutaneously and intravenously via cell suspensions. Tansplanted tumors are very similar to spontaneous tumors in terms of early formation phases. They are preferred in pharmaceutical studies.

\section{Ehrlich Acid Tumor}

EAT first appeared as a spontaneous breast adenocarcinoma in a female mouse, and Ehrlich \& Apolant (1905) transformed the tumor into an experimental tumor by subcutaneously transplanting the mouse into the mouse. EAT is used as liquid form or solid form according to the purpose. If the ascitic fluid containing the tumor cell is injected intraperitoneally into the test animal, the ascitic form is injected subcutaneously and the solid form is obtained. Figure 1 shows the cells of the acid form.

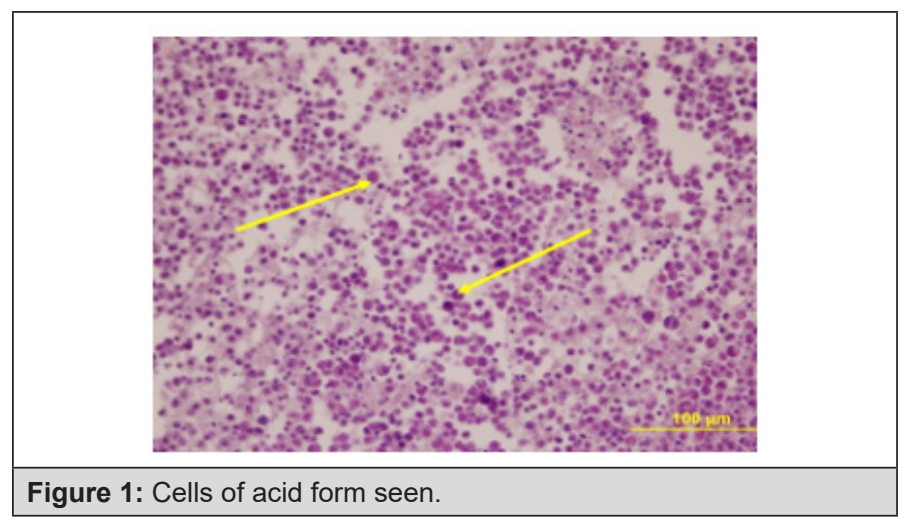

Solid form: Derived from Ehrlich Mouse Carcinoma, which was extracted from the mouse mammary gland in 1907 by Ehrlich and Apolant. It is a common tumor model currently used in mice. It has fast growth feature. Tumor cells are not of equal size and have a diameter of 20-30 microns. Cell suspension is applied subcutaneously to obtain solid tumor. When a 1x106 / ml cell suspension is injected subcutaneously, solid tumor is observed to be measurable at the end of 1 week. If the treatment is not performed, death is observed in mice within approximately 6 weeks (Figure 2).

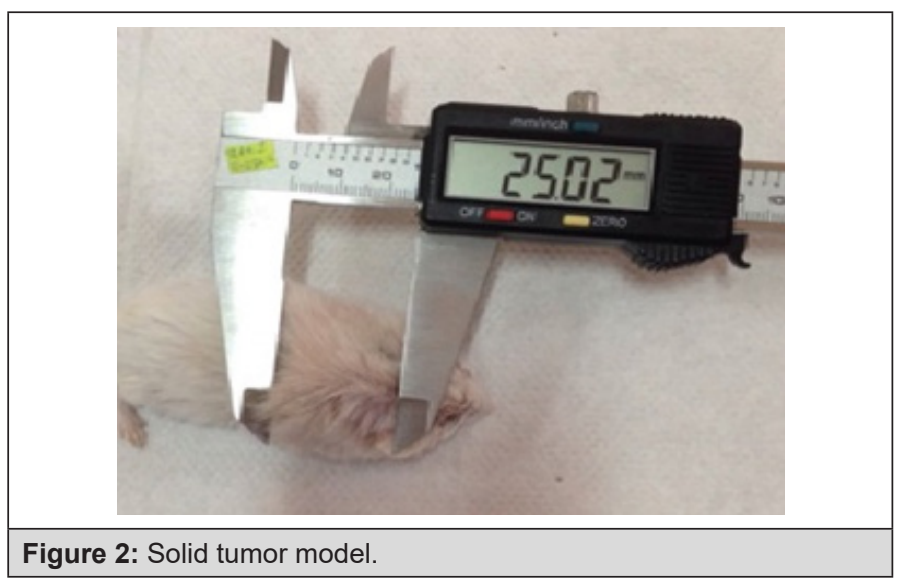

Liquid (Acid) Form: When 500,000 / ml cells were administered intraperitoneally to mice, it was seen that the tumor was in liquid form. Without treatment, deaths begin one week after tumor injection. If $2 \times 106 / \mathrm{ml}$ cells are injected, a tumor with a diameter of $1 \mathrm{~cm}$ occurs after 1 week. In smear preparations, it is observed that the cells belonging to the liquid form resemble the solid form cells. However, while the cell membranes of the solid form are not noticed, the membrane in liquid form is observed (Figure 3).

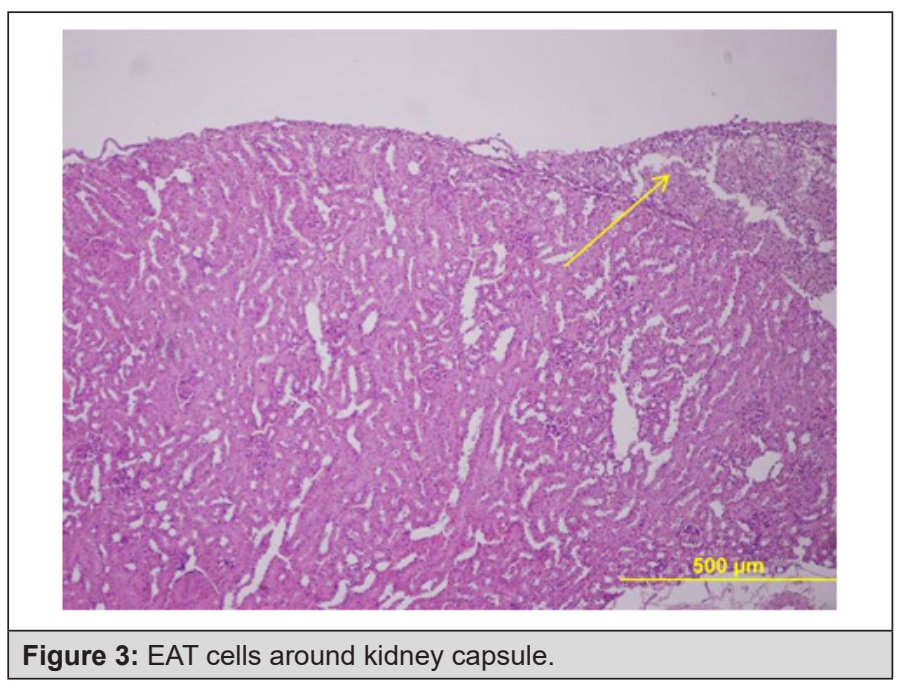

Lung cancer models:

a. Xenograft model: Tumor cells are transplanted to an area of the organ. This expensive and unusual method is used for in vivo evaluations of cytotoxic agents in the organ in lung cancer.

b. Orthotopic xenograft model: Intrathoracic implantation directly through the wig. There is a possibility that the suspension may escape the pleural area abdominal wall or lung parenchyma. In this model, the development of individualized treatment is very effective. 
Syngeneic model: It occurs by injecting immunologically compatible cancer cells into immunologically compatible mice. This model is difficult to construct.

Transgenic models: Transgenic mice are provided by microinjection of DNA into the pronucleus of the zygote. Thus, tumor formation can only be achieved in the lung. Transgenic mice are important for investigating cancer formation and development of genetic abnormalities.

Tumor Xenograft model: Nude mice can be subcutaneously, intravenously, intraperitoneally, tumor cell transplantation using an orthotopic model. After human tumor cells are transplanted into nude mice, the tumor cells undergo kinetic changes. Usually the tumor grows in a short time. Human tumors in nude mice treated with drugs appear to correlate clinically with subsequent studies. It has been shown in tumor xenografts such as small cell lung cancer, breast cancer, colon cancer.

\section{Discussion}

A wide range of animal models, all different because of the characteristics of the study can be selected depending on the purpose.

In the study of Ertekin et al. In one study, male 8-week-old Balb/C male colon cancer was performed with 1,2-dimethylhydrazine (DMH). As a result of the study, it was determined that combination of high dose angiostat with radiation, gene therapy or chemotherapy may be successful in cancer treatment. It was emphasized that further studies are needed to determine the antitumor effects of angiostatine [12].

Ströbel et al. In his study, male Spraque-Dawley rats were administered $1 \mathrm{mg} / \mathrm{kg}$ N-nitrosine morpholine orally for 20 months and examined liver tumors [13].

At six weeks of age, Wistar Albino male rats were initiated with 100 ppm MNNG (N-methyl-N-nitros-N-nitrosoguanidine) in a 5\% $\mathrm{NaCl}$ solution followed by MX (3-chloro-4), a mutagen for water. 57 weeks. - (dichloromethane) -5-hydroxy-2 (5H) -furanone) is administered at a dose of $30 \mathrm{ppm}$ to produce gastric cancer [14].

Lung cancer xenograft models, transgenic animal models, syngenic models and chemical lung tumor formation characteristics are examined [15].

Seher et al. studied the anti-tumoral structure of curcumin on the effect of solid and liquid tumors for Ehrlich ascites [16].

\section{Conclusion}

As a result, preclinical research is continuing in many fields such as cancer formation, development, metastasis, immune system response, cancer drug therapy and many researches are being done to solve the molecular and cellular structure of cancer. Which cancer type will be searched, which cell type to look for, whether there are genetic abnormalities Whether tissue is specific to a particular developmental time and tissue, whether spatial and temporal expression of a target gene should be controlled, the microenvironment of the tumor and the potential for metastasis should be considered.

\section{References}

1. Ferlay J, Soerjomataram I, Dikshit R, Eser S, Mathers C, et al. (2015) Cancer incidence and mortality worldwide: sources, methods and major patterns in GLOBOCAN 2012. Int J Cancer 136(5): E359-E386.

2. Stanton AL, Luecken LJ, MacKinnon DP, Thompson EH (2013) Mechanisms in psychosocial interventions for adults living with cancer: opportunity for integration of theory, research, and practice. J Consult Clin Psychol 81: 318-335.

3. Batty GD, Russ TC, Stamatakis E, Kivimäki M (2017) Psychological distress in relation to site specific cancer mortality: pooling of unpublished data from 16 prospective cohort studies. BMJ 356: j108.

4. Ceylan D, Aksoy A, Ertekin E, Yay AH, Nisari M, et al. (2019) The effects of gilaburu (Viburnum opulus) juice on experimentally induced Ehrlich ascites tumor in mice. Journal of Cancer Research and Therapeutics 14(2): 314-320.

5. Connolly JL, Schnitt SJ, Wang HH, Dvorak AM, Dvorak HF (2000) Principles of cancer pathology. Bast RC et al. (Editors) Cancer Medicine pp. 533-555.

6. Hanson Frost M, Suman VJ, Rummans TA, Dose AM, Taylor M, et al. (2000) Physical, psychological and social well- being of women with breast cancer: the influence of disease phase. Psychooncology 9(3): 221-231.

7. Yllmaz H, Ertekin T, Atay E, Nisari M, Güler HS, et al. (2018) Antioxidant role of melatonin against nicotine's teratogenic effects on embryonic bone development. Iran J Basic Med Sci 21: 787-793.

8. Atay E, Ertekin T, Yllmaz H, Güler HS, Al Ö, et al. (2019) Impact of prenatal exposure to bisphenol A on pregnant rats: Fetal bone development and immunohistochemistry implications. Toxicology and Industrial Health 35(2): 119-135.

9. Yılmaz S, Alpa Ş, Nisari M, Karatoprak GŞ, Doğanyiğit Z et al. (2019) Examining the Antitumoral Effect of Cornelian Cherry (Cornus mas) in Ehrlich Ascites Tumor-induced Mice. Journal of the anatomical society of india 68(1): 16-22.

10. Nisari M, Yllmaz S, Eroz R, Ertekin T, Bircan D, et al. (2017) The detection of curcumins antitumoral effects via argyrophilic nucleolar organizing region-associated protein synthesis in mice with ehrlich's ascitic carcinoma. Bratisl Med 118(1): 61-65.

11. Nisari M, Yllmaz S, Ertekin T, Ceylan D, İnanç N, et al. (2017) Effects of Curcumin on Lipid Peroxidation and Antioxidant Enzymes in Kidney, Liver, Brain and Testis of Mice Bearing Ehrlich Solid Tumor. MDPI Journal 1(10): 994.

12. Ertekin T, Ekinci N, Karaca O, Nisari M, Canoz O et al. (2013) Effect of angiostatin on 1,2-dimethylhydrazine-induced colon cancer in mice. Toxicology and Industrial Health 29(6): 490-497.

13. Ströbel P, Klimek F, Zerban H, Kopp-Schneider, Bannasch P (1998) Xenomorfik hepatoselüler prekürsörler ve düşük dozlarda $\mathrm{N}$-nitrosomorfolinli sıçanlarda indüklenen tigroid hücre odaklarının neoplastik ilerlemesi. Carcinogenesis 19: 2069-2080.

14. Nishikawa A, Furukawa F, Lee IS, Kasahara K, Tanakamaru Z, et al. (1999) Promo-ting effects of 3-chloro-4-(dichloromethyl)-5-hydroxy$2(5 \mathrm{H})$-furanone on rat glandular stomach carcinogenesis initiated with N-methyl-N'-nitro-N-nitrosoguanidine. Cancer Res 59: 2045-2049.

15. Üstüner c, Entok E (2019) Akciğer Kanseri Deneysel Modelleri. Nuci Med Semin 5: 40-48.

16. Yılmaz S, Ertekin T, Ulger H, Yay A, Acer N, et al. (2019) Investigating the anti-tumoral effect of curcumin on the mice in which Ehrlich ascites and solid tumor is created. Iran J Basic Med Sci 22(4): 418-4425. 